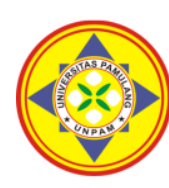
PERPUSS

\title{
PENGARUH GAYA KEPEMIMPINAN DAN DISIPLIN KERJA TERHADAP KINERJA KARYAWAN PADA PT FA ANTARES MEDIKA BSD CITY
}

\author{
${ }^{1 *}$ Rahmi Hermawati, ${ }^{2}$ Tri Hastuti, ${ }^{3}$ Mohammad Ahyar Syafwan Lysander \\ 1.2Universitas Pamulang, Tangerang Selatan, Banten, Indonesia \\ ${ }^{3}$ Universitas Sarjanawiyata Tamansiswa, Yogyakarta, Indonesia \\ *dosen000871@unpam.ac.id
}

\begin{abstract}
Abstrak
Penelitian ini bertujuan untuk mengetahui adakah pengaruh atau seberapa besarkah pengaruh variabel Gaya kepemimpinan dan disiplin kerja terhadap kinerja karyawan PT. Fa Antares Medika BSD City. Metode yang digunakan dalam penelitian ini adalah metode kuantitatif, dimana teknik pengumpulan data yang digunakan dengan penyebaran kuesioner,Observasi dan data pustaka. Sampel dalam penelitian ini adalah karyawan PT. Fa Antares Medika - BSD City yang berjumlah 50 orang dengan metode sampel jenuh. Metode yang digunakan adalah regresi linear berganda. Dari hasil pengolahan data menggunakan SPSS 26 didapati bahwa Adjusted R Square sebesar 52,7\%. Artinya, variabel Gaya Kepemimpinan dan Disiplin Kerja dapat menjelaskan variabel Kinerja sebesar 52,7\%. Selisihnya, dipengaruhi oleh variabel lain yang tidak digunakan dalam penelitian ini. Hasil dari penelitian ini menyimpulkan bahwa secara parsial, variabel Gaya kepemimpinan dan disiplin kerja berpengaruh signifikan terhadap kinerja karyawan PT. Fa Antares Medika - BSD City. Secara simultan Gaya kepemimpinan dan disiplin kerja berpengaruh terhadap Kinerja karyawan. .
\end{abstract}

Kata Kunci: Gaya Kepemimpinan, Disiplin Kerja, Kinerja Karyawan

\section{Abstract}

This study aims to determine whether there is any influence or how much influence the variables of leadershipstyle and work discipline on the performance of employees of PT. Fa Antares Medika - BSD City The method used in this research is quantitative method, where the data collection technique used is by distributing questionnaires, observation and library data. The sample in this study were employees of PT. Fa AntaresMedika - BSD City, amounting to 50 people with a saturated sample method. The method used is multiple linear regression. From the results of data processing using SPSS 26, it was found that the Adjusted $R$ Square was $52,7 \%$. That is, the variable leadership style and work discipline can explain the performance variable by $52,7 \%$. The difference is influenced by other variables that are not used in this study. The results of this study concluded that partially, the variables of leadership style and work discipline have a significant effect on the performance of employees of PT. Fa Antares Medika - BSD City. Simultaneously, leadership style and work discipline affect employee performance.

Keywords: Leadership style, Work discipline, Employee performance

\section{PENDAHULUAN}

Perusahaan secara umum adalah tempat terjadinya kegiatan produksi dan berkumpulnya semua faktor produksi. Pada dasarnya setiap perusahaan yang didirikan mempunyai harapan bahwa kelak dikemudian hari akan mengalami perkembangan yang pesat di dalam lingkup usaha dari perusahaannya dan menginginkan terciptanya kinerja yang tinggi dalam bidang pekerjaannya. Oleh karena itu keberadaaan suatu perusahaan yang berbentuk apapun baik dalam skala besar maupun kecil tidak terlepas dari unsur sumber daya manusia.

Sumber daya manusia merupakan salah satu faktor yang ikut terlibat secara langsung dalam menjalankan kegiatan perusahaan dan berperang penting dalam meningkatkan kinerja perusahaan dalam mencapai tujuan yang telah ditetapkan, sebagaimana Hasibuan (2016:11) menyampaikan bahwa tujuan tidak mungkin terwujud tanpa peran aktif 
karyawan meskipun alat-alat yang dimiliki perusahaan begitu canggihnya" Oleh karena itu keberhasilan suatu perusahaan tidak hanya tergantung dengan teknologi perusahaan saja namun juga tergantung pada aspek sumber daya manusia yang dimiliki oleh perusahaan. Sehingga suatu perusahaan membutuhkan sumber daya manusia yang potensial, baik pemimpin maupun karyawan dapat memberikan kontribusi yang baik dan melaksanakan tugas dengan optimal untuk mencapai tujuan perusahaannya. Karena semua kegiatan perusahaan akan melibatkan tindakan sumber daya manusia yang ada didalamnya. Lebih lanjut Hasibuan (2016 : 12) juga menyampaikan bahwa “ Manajemen merupakan ilmu dalam mengatur pemanfaatan sumber daya manusia secara efektif untuk mencapai suatu tujuan tertentu.

Kinerja merupakan salah satu komponen yang harus dimiliki oleh suatu lembaga atau perusahaan apabila ingin mencapai tujuan yang telah ditetapkan, sebagaimana Ratundo dan Sacket (2012:76) menyampaikan bahwa Kinerja adalah kegiatan yang mencakup semua tindakan atau perilaku yang dikontrol oleh individu dan memberi kontribusi pada pencapaian tujuan-tujuan perusahaan. Tinggi rendahnya kinerja seseorang juga dapat dipengaruhi oleh faktor gaya kepemimpinan. Menurut Fahmi (2016 : 122) gaya kepemimpinan merupakan suatu ilmu yang mengkaji secara komprehensif tentang bagaimana mengarahkan, mempengaruhi, dan mengawal orang lain untuk mengerjakan tugas sesuai dengan perintah yang direncanakan. Dapat disimpulkan gaya kepemimpinan adalah pola tingkah laku (kata-kata dan tindakan-tindakan) dari seorang pemimpin yang dirasakan oleh orang lain. Gaya atau model pemimpin ada yang disenangi bawahannya dan ada juga yang tidak disenangi. Jika, pemimpin memberikan gaya yang baik dan sesuai, maka kinerja bawahan juga akan meningkat baik pula.

Namun seringkali pemimpin. sudah memberikan kepemimpinan yang sesuai, namun bawahan masih ada yang semaunya sendiri. Dengan gaya kepemimpinan yang baik, maka karyawan akan mengikutinya. Selain gaya kepemimpinan ternyata kinerja juga dapat dipengaruhi oleh faktor lainnya seperti disiplin kerja. Menurut Hasibuan (2016:193) disiplin merupakan kesadaran dan kesediaan seseorang menaati semua peraturan perusahaan dan norma-norma sosial yang berlaku. Bisa diambil kesimpulannya bahwa kedisiplinan merupakan suatu keadaan tertentu dimana orang-orang dalam suatu organisasi dalam hal ini adalah karyawan tunduk pada peraturan yang berlaku tertulis maupun tidak tertulis yang bilamana dilanggar akan mendapatkan sanksi yang sudah diatur.

PT. Fa Antares Medika merupakan perusahaan yang bergerak dibidang distributor alat-alat kesehatan yang menjual barang-barang perlengkapan bedah maupun habis pakai. Karena bergerak dalam bidang kesehatan, maka diperlukannya kepemimpinan yang baik untuk mengatur pendisitribusian, pimpinan harus memiliki kepribadian yang patut dicontoh atau ditiru oleh bawahannya. Namun dari teori tersebut berbeda dengan kenyataan dilapangan, yakni dari karyawan PT. Fa Antares Medika mengatakan bahwa gaya kepemimpinannya masih kurang jelas dalam memberikan intruksi kepada bawahannya, sehingga menyebabkan dalam bekerja karyawan kurang mengerti bagaimana cara kinerja mereka. Tidak hanya itu, sifat pemimpin yang hanya diam, tidak berani menegur karyawan yang kurang sesuai serta tingkat keprihatinan yang masih dibutuhkan. Sehingga dengan gaya tersebut maka akan mempengaruhi karyawannya.

Selain gaya kepemimpinan yang berpengaruh terhahap kinerja adapun faktor lainnya yaitu disiplin kerja. Disiplin kerja adalah suatu alat yang digunakan para manajer untuk berkomunikasi dengan karyawan agar mereka bersedia untuk mengubah suatu perilaku serta sebagai suatu upaya untuk meningkatkan kesadaran dan kesediaan seseorang 
menaati semua peraturan perusahaan dan norma-norma sosial yang berlaku. Tidak hanya itu disiplin kerja yang tinggi secara otomatis akan menghasilkan kinerja yang baik pula.

Setelah dilakukan observasi dan pra penelitian di PT. FA Antares Medika, terlihat masih banyak karyawan yang telat saat masuk kerja, tidak disiplin, kurang komunikasi antar karyawan dengan pimpinan, saat jam kerja keluar dari kantor sehingga menurunya kualitas kerja karyawan.

Berdasarkan latar belakang permasalahan diatas, maka penulis tertarik untuk melakukan penelitian lebih lanjut dengan judul "Pengaruh Gaya Kepemimpinan Dan Disiplin Kerja Terhadap Kinerja Karyawan Pada PT. Fa Antares Medika Di BSD City".

\section{TINJAUAN PUSTAKA}

\section{Kinerja Karyawan}

Mangkunegara

pengertian kinerja (prestasi kerja) adalah hasil kerja secara kualitas dan kuantitas yang dicapai oleh seorang pegawai dalam melaksanakan tugasnya sesuai dengan tanggung jawab yang diberikan kepadanya. Adapun indikator yang mempengaruhi kinerja antara lain:

a. Kualitas kerja

Kualitas kerja adalah seberapa baik seorang karyawan mengerjakan apa yang seharusnya dikerjakan.

b. Kuantitas kerja

Kuantitas kerja adalah seberapa lama seorang pegawai bekrja dalam satu harinya. Kuantitas kerja ini dapat dilihat dari kecepatan kerja setiap pegawai itu masing-masing

c. Pelaksanaan Tugas

Pelaksanaan tugas adalah seberapa jauh karyawan mampu melakukan pekerjaannya dengan akurat atau tidak ada kesalahan.

d. Tanggung Jawab

Tanggung jawab terhadap pekerjaan adalah kesadaran akan kewajiban karyawan untuk melaksanakan pekerjaan yang diberikan perusahaan.

\section{Gaya Kepemimpinan}

Menurut Rivai

menyatakan Gaya Kepemimpinan adalah sekumpulan ciri yang digunakan pimpinan untuk memengaruhi bawahan agar sasaran organisasi tercapai atau dapat pula dikatakan bahwa gaya kepemimpinan adalah pola perilaku dan strategi yang disukai dan sering diterapkan oleh seorang pemimpin. Adapun indikator gaya kepemimpinan meliputi:

a. Sifat.

Sifat merupakan Seorang pemimpin mampu belajar dan melatih dirinya sendiri serta mampu mengajari, melatih dan memberi contoh kepada orang lain yang di pimpinnya.

b. Kebiasaan

Kebiasaan merupakan serangkaian perbuatan seseorang pemimpin secara berulang-ulang dengan cara yang sama dan berlangsung tanpa proses berpikir lagi.

c. Tempramen

Temperamen merupakan gaya perilaku seorang pemimpin dan cara khasnya dalam memberi tanggapan dalam berinteraksi dengan orang lain.

d. Watak

Watak seorang pemimpin merupakan sifat batin yang mempengaruhi segenap pikiran, perilaku, budii pekerti, dan tabiat yang dimiliki seorang pemimpin.

\section{Disiplin Kerja}

Menurut Veitzhzal Rivai (2016:44) berpendapat bahwa "Disiplin Kerja merupakan Suatu alat yang digunakan para manajer untuk berkomunikasi dengan karyawan agar mereka bersedia untuk mengubah suatu perilaku serta sebagai suatu upaya untuk meningkatkan kesadaran dan kesediaan seseorang mentaati semua peraturan perusahaan dan norma-norma sosial yang berlaku". Adapun indikator yang 
digunakan meliputi:

a. Frekuensi kehadiran

Frekuensi kehadiran adalah Menyangkut tingkat kehadiran ditempat kerja, Tingkat ketetapan datang dan meninggalkan tempat kerja, Tingkat komitmen pegawai untuk selalu berada di kantor selama jam kerja.

b. Tingkat kewaspadaan

Tingkat kewaspadaan adalah Tingkat efektif dan efisien dalam pemakaian peralatan kerja, Tingkat kehati-hatian dalam menggunakan peralatan kerja,Tingkat penjagaan dan perawatan peralatan kerja.

c. Ketaatan pada standar kerja

Ketaatan pada strandar kerja adalah Tingkat pertanggung jawaban pegawai terhadap pekerjaan, Tingkat memahami fungsi dan tugas pegawai dalam bekerja.

d. Ketaatan peraturan kerja

Ketaatan peraturan kerja adalah Tingkat pemahaman terhadap peraturan kerja, Tingkat kesadaran pegawai untuk taat terhadap peraturan, Tingkat pemahaman pegawai terhadap hak dan kewajiban sebagai seorang pegawai.

e. Etika kerja

Etika kerja adalah Tingkat kesopanan pegawai dalam bekerja, Tingkat kejujuran dalam bekerja, Tingkat efisiensi pembinaan etika kerja pegawai oleh perusahaan

\section{METODE}

Penelitian ini dilaksanakan di PT. Fa Antares Medika di alamat Blok I No. 7-8, BSD, Kompleks Golden Boulevard, Lengkong Karya, Tangerang, Kota Tangerang Selatan, Banten. Jumlah populasi dalam penelitian ini sebanyak 50 karyawan. Dengan menggunakan metode sampel jenuh peneliti mengambil sampel sebanyak 50 karyawan. Metode penelitian yang digunakan dalam penelitian ini adalah metode kuantitatif. Pengumpulan data dilakukan dengan menyebar kuesioner kepada karyawan. Analisis data yang digunakan dalam penelitian ini diolah dengan bantuan Software IBM SPSS (Statistical Program for Social Science) versi 26 for windows.

\section{HASIL DAN PEMBAHASAN}

\section{Analisis Deskriptif}

Pada pengujian ini digunakan untuk mengetahui skor minimum dan maksimum, mean score dan standar deviasi dari masing-masing variabel. Adapun hasilnya sebagai berikut:

a. Berdasarkan jawaban responden terhadap variabel kinerja karyawan diperoleh rata-rata skor sebesar 3.88 termasuk pada rentang skala 3,40-4,19 dengan kriteria setuju, artinya mayoritas responen memberikan jawaban setuju. Responden yang menjawab sangat setuju dan setuju sebesar 70,4\% dan responden yang menjawab kurang setuju dan tidak setuju mencapai $29,6 \%$.

b. Berdasarkan jawaban responden atas pernyataan pada variabel gaya kepemimpinan diperoleh rata-rata skor 3.79 termasuk pada rentang skala 3,40-4,19 dengan kriteria setuju, artinya mayoritas responen memberikan jawaban setuju.Responden yang menjawab sangat setuju dan setuju sebesar $65,0 \%$ dan responden yang menjawab kurang setuju dan tidak setuju mencapai 35,0\%.

c. Berdasarkan jawaban responden pada variabel disiplin kerja diperoleh ratarata skor 3.80 termasuk pada rentang skala 3,40-4,19 dengan kriteria setuju, artinya mayoritas responen memberikan jawaban setuju. Responden yang menjawab sangat setuju dan setuju sebesar $63,2 \%$ dan responden yang menjawab kurang setuju dan tidak setuju mencapai $36,8 \%$. 


\section{Analisis Kuantitatif}

Pada analisis ini dimaksudkan untuk mengetahui pengaruh variabel independen terhadap variabel dependen. Adapun hasil pengujian sebagai berikut: a. Analisis Regresi Linier Berganda

Uji regresi ini dimaksudkan untuk mengetahui perubahan variabel dependen jika variabel independen mengalami perubahan. Adapun hasil pengujiannya sebagai berikut:

Tabel 1. Hasil Pengujian Regresi Berganda Variabel Gaya Kepemimpinan (X1) dan Disiplin Kerja

(X2) Terhadap Kinerja Karyawan (Y)

Coefficient

\begin{tabular}{|c|c|c|c|c|c|}
\hline \multirow[t]{2}{*}{ Model } & \multicolumn{2}{|c|}{ Unstandardized Coefficients } & \multirow{2}{*}{$\begin{array}{c}\text { Standardized Coefficients } \\
\text { Beta }\end{array}$} & \multirow[b]{2}{*}{$t$} & \multirow[b]{2}{*}{ Sig. } \\
\hline & B & Std. Error & & & \\
\hline 1 (Constant) & 9.773 & 3.794 & & 2.576 & .013 \\
\hline Disiplin Kerja (X1) & .379 & .106 & .41 & 3.592 & .001 \\
\hline Motivasi (X2) & .382 & .106 & .41 & 3.614 & .001 \\
\hline
\end{tabular}

a. Dependent Variable: Kinerja Karyawan (Y)

Berdasarkan hasil analisis perhitungan regresi pada tabel di atas, maka dapat diperoleh persamaan regresi $Y=10,270+0,368 X 1+0,385 X 2$. Dari persamaan di atas maka dapat disimpulkan sebagai berikut:

1) Nilai konstanta sebesar 10,270 diartikan bahwa jika variabel gaya kepemimpinan (X1) dan disiplin kerja (X2) tidak dipertimbangkan maka Kinerja Karyawan (Y) hanya akan bernilai sebesar 10,270 point.

2) Nilai gaya kepemimpinan (X1) 0,368 diartikan apabila konstanta tetap dan tidak ada perubahan pada variabel disiplin kerja $(X 2)$, maka setiap perubahan 1 unit pada variabel gaya kepemimpinan (X1) akan mengakibatkan terjadinya perubahan pada Kinerja Karyawan
(Y) sebesar 0,368 point.

3) Nilai disiplin kerja (X2) 0,385 diartikan apabila konstanta tetap dan tidak ada perubahan pada variabel gaya kepemimpinan (X1), maka setiap perubahan 1 unit pada variabel disiplin kerja (X2) akan mengakibatkan terjadinya perubahan pada Kinerja Karyawan (Y) sebesar 0,385 point.

\section{b. Analisis Koefisien Korelasi}

Analisis koefisien korelasi dimaksudkan untuk mengetahui tingkt kekuatan hubungan dari variabel independen terhadap variabel dependen baik secara parsial maupun simultan. Adapun hasil pengujian sebagai berikut:

Tabel 2. Korelasi Secara Parsial Antara Gaya Kepemimpinan ( $\left.\mathrm{X}_{1}\right)$ Terhadap Kinerja Karyawan (Y)

\section{Correlations $^{b}$}

\begin{tabular}{|c|c|c|c|}
\hline & & $\begin{array}{c}\text { Gaya } \\
\text { Kepemimpinan } \\
(\mathrm{X} 1)\end{array}$ & $\begin{array}{r}\text { Kinerja } \\
\text { Karyawan }(\mathrm{Y})\end{array}$ \\
\hline \multirow{2}{*}{$\begin{array}{l}\text { Gaya Kepemimpinan } \\
\text { (X1) }\end{array}$} & Pearson Correlation & 1 & $.650^{* *}$ \\
\hline & Sig. (2-tailed) & & .000 \\
\hline \multirow[t]{2}{*}{ Kinerja Karyawan (Y) } & Pearson Correlation & $.650^{* *}$ & 1 \\
\hline & Sig. (2-tailed) & .000 & \\
\hline
\end{tabular}

Berdasarkan hasil pengujian pada tabel di atas, diperoleh nilai Koefisien korelasi sebesar 0,650 dimana nilai tersebut berada pada interval 0,600-0,799 artinya kedua variabel 
memiliki tingkat hubungan yang

kuat.

Tabel 3. Hasil Analisis Koefisien Korelasi Secara Parsial Antara Disiplin Kerja $\left(\mathrm{X}_{2}\right)$ Terhadap Kinerja Karyawan $(\mathrm{Y})$

Correlations $^{\mathrm{b}}$

\begin{tabular}{l|l} 
Disiplin Kerja (X2) & Kinerja Karyawan (Y) \\
\hline
\end{tabular}

\begin{tabular}{lcc|c}
\hline Disiplin Kerja (X2) & Pearson Correlation & 1 & $.655^{* *}$ \\
\cline { 2 - 4 } & Sig. (2-tailed) & .000 \\
\hline Kinerja Karyawan (Y) & Pearson Correlation & $.655^{* *}$ & 1 \\
\cline { 2 - 4 } & Sig. (2-tailed) & .000 & \\
\hline \multicolumn{2}{c}{ **. Correlation is significant at the 0.01 level (2-tailed). } \\
b. Listwise N=50
\end{tabular}

Berdasarkan pada hasil pengujian pada tabel di atas, diperoleh nilai Koefisien korelasi sebesar 0,655 dimana nilai tersebut berada pada interval 0,600-0,799 artinya kedua variabel memiliki tingkat hubungan yang kuat

Tabel 4. Hasil Analisis Koefisien Korelasi Secara Simultan Antara Gaya Kepemimpinan $\left(X_{1}\right)$ dan Disiplin Kerja $\left(\mathrm{X}_{2}\right)$ Terhadap Kinerja Karyawan $(\mathrm{Y})$

Model Summary

$\begin{array}{llll}\text { Model R } & \text { R Square } & \text { Adjusted R Square } & \text { Std. Error of the Estimate }\end{array}$

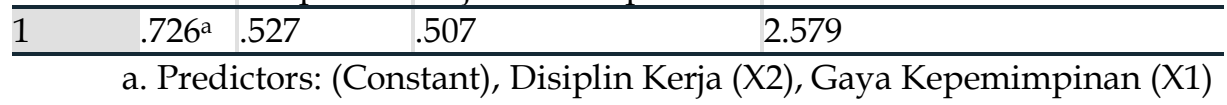

Berdasarkan pada hasil pengujian pada tabel di atas, diperoleh nilai Koefisien korelasi sebesar 0,726 dimana nilai tersebut berada pada interval 0,600-0,799

artinya variabel gaya kepemimpinan dan disiplin kerja mempunyai tingkat hubungan yang kuat terhadap Kinerja Karyawan.

\section{c. Analisis Koefisien Determinasi}

Tabel 5. Hasil Analisis Koefisien Determinasi Secara Parsial Antara Gaya Kepemimpinan $\left(X_{1}\right)$ Terhadap Kinerja Karyawan (Y)

\begin{tabular}{cc|c|c|c} 
& & \multicolumn{2}{c}{ Model Summary } & \\
Model & $R$ & R Square & Adjusted R Square & $\begin{array}{c}\text { Std. Error of the } \\
\text { Estimate }\end{array}$ \\
\hline 1 & $.650^{\mathrm{a}}$ & .423 & .411 & 2.818 \\
\hline
\end{tabular}

a. Predictors: (Constant), Gaya Kepemimpinan (X1)

Berdasarkan hasil pengujian pada tabel di atas, diperoleh nilai Koefisien determinasi sebesar 0,423 maka dapat disimpulkan bahwa variabel gaya kepemimpinan

Tabel 6. Hasil Analisis Koefisien Determinasi Secara Parsial Antara Disiplin Kerja (X2) Terhadap Kinerja Karyawan (Y)

\section{Model Summary}

Model R R Square Adjusted R Square Std. Error of the Estimate

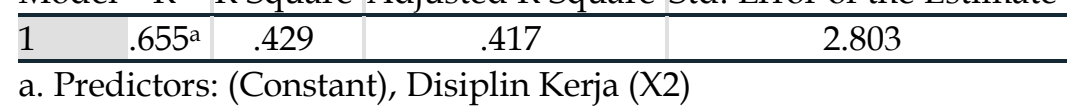

Berdasarkan pada hasil pengujian pada tabel di atas, diperoleh nilai Koefisien determinasi berpengaruh terhadap variabel Kinerja Karyawan sebesar $42,3 \%$ sedangkan sisanya sebesar (100$42,3 \%)=57,7 \%$ dipengaruhi faktor lain. 
Kinerja Karyawan sebesar $42,9 \%$ sedangkan sisanya sebesar (100Tabel 7. Hasil Analisis Koefisien Determinasi Secara Simultan Antara Gaya Kepemimpinan $\left(\mathrm{X}_{1}\right)$ dan Disiplin Kerja $\left(\mathrm{X}_{2}\right)$ Terhadap Kinerja Karyawan (Y)

\section{Model Summary}

\begin{tabular}{ll|l|l|l} 
Model & R & R Square & Adjusted R Square & Std. Error of the Estimate \\
\hline 1 & $.726^{a}$ & .527 & .507 & 2.579 \\
\hline & a. Predictors: (Constant), Disiplin Kerja (X2), Gaya Kepemimpinan (X1)
\end{tabular}

Berdasarkan pada hasil pengujian pada tabel di atas, diperoleh nilai Koefisien determinasi sebesar 0,527 maka dapat disimpulkan bahwa variabel gaya kepemimpinan dan disiplin kerja berpengaruh terhadap variabel Kinerja Karyawan sebesar $52,7 \%$ sedangkan sisanya sebesar (100$52,7 \%)=47,3 \%$ dipengaruhi faktor lain yang tidak dilakukan penelitian.

Tabel 8. Hasil Uji Hipotesis (Uji t) Variabel Gaya Kepemimpinan $\left(X_{1}\right)$ Terhadap Kinerja Karyawan $(Y)$

Coefficients $^{\mathrm{a}}$

Unstandardized Coefficients Standardized Coefficients $t \quad$ Sig.

\begin{tabular}{llllll} 
Model & B & Std. Error & Beta & \\
\hline 1 (Constant) & 16.022 & 3.868 & & 4.142 .000 \\
\hline Gaya kepemimpinan $(\mathrm{X} 1) .602$ & .101 & .650 & 5.931 .000 \\
\hline
\end{tabular}

a. Dependent Variable: Kinerja Karyawan (Y)

Berdasarkan pada hasil pengujian pada tabel di atas diperoleh nilai $t_{\text {hitung }}>t_{\text {tabel }}$ atau $(5,931>2,011)$ Hal tersebut juga diperkuat dengan nilai $\rho$ value < Sig. 0,05 atau $(0,000<$ $0,05)$. Dengan demikian maka $\mathrm{H}_{0}$ ditolak dan $\mathrm{H}_{1}$ diterima, hal ini menunjukkan bahwa terdapat

Tabel 9. Hasil Uji t Variabel Disiplin Kerja $\left(\mathrm{X}_{2}\right)$ Terhadap Kinerja Karyawan (Y)

\section{Coefficients $^{\mathrm{a}}$}

Unstandardized Coefficients Standardized Coefficients

\begin{tabular}{lcc|ccc} 
Model & B & Std. Error & Beta & T Sig. \\
\hline 1 (Constant) & 15.471 & 3.910 & & 3.957 .000 \\
\hline Disiplin Kerja (X2) & .615 & .102 & .655 & 6.007 .000 \\
\hline
\end{tabular}

a. Dependent Variable: Kinerja Karyawan $(\mathrm{Y})$

Berdasarkan pada hasil pengujian pada tabel di atas diperoleh nilai $t_{\text {hitung }}>t_{\text {tabel }}$ atau $(6,007>2,011)$. Hal tersebut juga diperkuat dengan nilai $\rho$ value < Sig. 0,05 atau $(0,000<$ 0,05). Dengan demikian maka $\mathrm{H}_{0}$ ditolak dan $\mathrm{H}_{2}$ diterima, hal ini pengaruh yang signifikan antara gaya kepemimpinan terhadap Kinerja Karyawan

Hipotesis kedua : Terdapat pengaruh yang signifikan antara disiplin kerja terhadap kinerja karyawan
Uji Hipotesis

Pengujian hipotesis dengan uji $t$ digunakan untuk mengetahui hipotesis parsial mana yang diterima. kepemimpinan terhadap kinerja karyawan. 
digunakan untuk mengetahui hipotesis simultan yang mana yang diterima.

pengaruh yang signifikan antara gaya kepemimpinan dan disiplin kerja Hipotesis ketiga Terdapat terhadap kinerja karyawan.

Tabel 10. Hasil Hipotesis (Uji F) Secara Simultan Antara Gaya Kepemimpinan (X1) dan Disiplin Kerja (X2) Terhadap Kinerja Karyawan (Y)

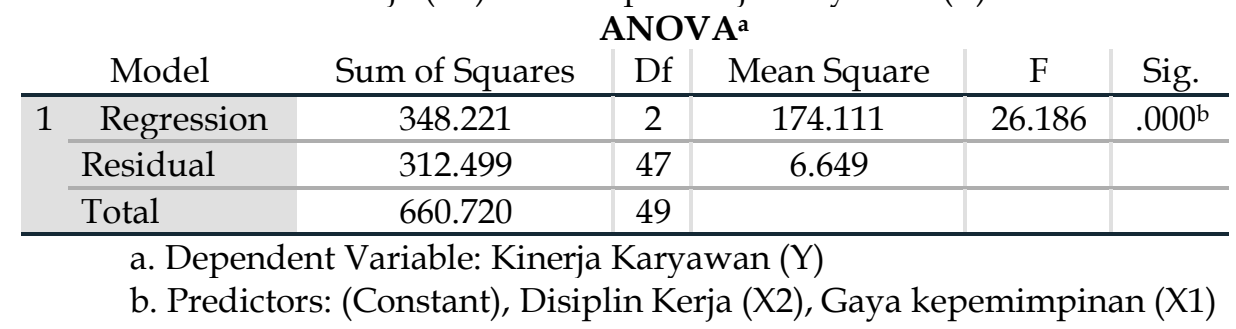

Berdasarkan pada hasil pengujian pada tabel di atas diperoleh nilai $F_{\text {hitung }}>\mathrm{F}$ tabel atau $(26,186>$ $2,800)$, hal ini juga diperkuat dengan $\rho$ value < Sig.0,05 atau $(0,000<0,05)$. Dengan demikian maka $\mathrm{H}_{0}$ ditolak dan $\mathrm{H}_{3}$ diterima, hal ini menunjukkan bahwa terdapat pengaruh yang signifikan secara simultan antara gaya kepemimpinan dan disiplin kerja terhadap Kinerja Karyawan pada PT. Fa Antares Medika di BSD City.

\section{PEMBAHASAN HASIL PENELITIAN}

1. Pengaruh Gaya Kepemimpinan terhadap Kinerja Karyawan

Gaya kepemimpinan berpengaruh signifikan terhadap kinerja karyawan dengan persamaan regresi $Y=16,022+$ $0,602 X 1$, nilai korelasi sebesar 0,650 artinya kedua variabel memiliki tingkat hubungan yang kuat dengan koefisien determinasi sebesar $42,3 \%$. Uji hipotesis diperoleh $\mathrm{t}$ hitung $>\mathrm{t}$ tabel atau $(5,931>$ 2,011). Dengan demikian H0 ditolak dan H1 diterima artinya terdapat pengaruh signifikan antara gaya kepemimpinan terhadap kinerja karyawan.

2. Pengaruh Disiplin Kerja terhadap Kinerja Karyawan

Disiplin kerja berpengaruh signifikan terhadap kinerja karyawan dengan persamaan regresi $Y=15,471+$ $0,615 X 2$ nilai korelasi sebesar 0,655 artinya kedua memiliki tingkat hubungan yang kuat dengan koefisien determinasi sebesar $42,9 \%$. Uji hipotesis diperoleh $\mathrm{t}$ hitung $>\mathrm{t}$ tabel atau $(6,007>$ 2,011). Dengan demikian H0 ditolak dan $\mathrm{H} 2$ diterima artinya terdapat pengaruh signifikan antara disiplin kerja terhadap kinerja karyawan.

3. Pengaruh Gaya Kepeimpinan dan Disiplin kerja terhadap Kinerja Karyawan

Gaya kepemimpinan dan disiplin kerja berpengaruh signifikan terhadap kinerja karyawan dengan persamaan regresi $Y=10,270+0,368 X 1+0,385 X 2$. Nilai korelasi sebesar 0,726 artinya variabel bebas dengan variabel terikat memiliki tingkat hubungan yang kuat dengan koefisien determinasi sebesar $52,7 \%$ sedangkan sisanya sebesar $47,3 \%$ dipengaruhi faktor lain. Uji hipotesis diperoleh nilai $\mathrm{F}$ hitung $>\mathrm{F}$ tabel atau $(26,186>2,800)$. Dengan demikian HO ditolak dan H3 diterima. Artinya terdapat pengaruh signifikan secara simultan antara gaya kepemimpinan dan disiplin kerja terhadap kinerja karyawan di PT. Fa Antares Medika di BSD City.

\section{PENUTUP}

\section{Kesimpulan}

1. Gaya kepemimpinan berpengaruh signifikan terhadap kinerja karyawan dengan koefisien determinasi sebesar $42,3 \%$. Uji hipotesis diperoleh $t$ hitung $>$ $\mathrm{t}$ tabel atau $(5,931>2,011)$. Dengan demikian $\mathrm{H} 0$ ditolak dan $\mathrm{H} 1$ diterima artinya terdapat pengaruh signifikan antara gaya kepemimpinan terhadap kinerja karyawan. 
2. Disiplin kerja berpengaruh signifikan terhadap kinerja karyawan dengan dengan koefisien determinasi sebesar $42,9 \%$. Uji hipotesis diperoleh $\mathrm{t}$ hitung > $\mathrm{t}$ tabel atau $(6,007>2,011)$. Dengan demikian $\mathrm{H} 0$ ditolak dan $\mathrm{H} 2$ diterima artinya terdapat pengaruh signifikan antara disiplin kerja terhadap kinerja karyawan.

3. Gaya kepemimpinan dan disiplin kerja berpengaruh signifikan terhadap kinerja karyawan dengan nilai korelasi sebesar 0,726 artinya variabel bebas dengan variabel terikat memiliki tingkat hubungan yang kuat dengan koefisien determinasi sebesar 52,7\% sedangkan sisanya sebesar $47,3 \%$ dipengaruhi faktor lain. Uji hipotesis diperoleh nilai $F_{\text {hitung }}>$ $F$ tabel atau $(26,186>2,800)$. Dengan demikian $\mathrm{H}_{0}$ ditolak dan $\mathrm{H}_{3}$ diterima. Artinya terdapat pengaruh signifikan secara simultan antara gaya kepemimpinan dan disiplin kerja terhadap kinerja karyawan di PT. Fa Antares Medika di BSD City

\section{Saran}

1. Gaya kepemimpinan pernyataan yang paling lemah adalah nomor 1 yaitu Pemimpin bersifat tegas sesuai dengan peraturan yang berlaku dimana hanya mencapai rata-rata score sebesar 3,38 dengan presentase sebesar $35,0 \%$. Untuk lebih baik lagi perusahaan harus memiliki pemimpin yang mempunyai potensi yang tegas agar seorang pemimpin mampu melatih dan memberi contoh kepada orang lain yang di pimpinnya dengan tujuan yang ingin diperoleh atau yang diinginkan untuk mencapai tujuan bersama.

2. Disiplin kerja pernyataan yang paling lemah adalah nomor 1 yaitu Karyawan datang ketempat kerja lebih awal dari waktu yang telah ditentukan dimana hanya mencapai rata-rata score sebesar 3,38 dengan presentase sebesar $36,8 \%$.Untuk lebih baik lagi perusahaan harus membuat kesepakatan bersama bagi karyawan yang datang sebelum jam kantor akan diberikan penghargaan dan memberikan sanksi hukuman yang tegas bagi karyawan yang terlambat seperti memberlakukan punishment, misalnya memajang foto karyawan yang suka datang terlambat agar mereka tidak melakukan berkali-kali.

3. Kinerja karyawan pernyataan yang paling lemah adalah nomor 1 yaitu Karyawan menyelesaikan pekerjaan dengan teliti dimana hanya mencapai rata-rata score sebesar 3,36 dengan presentase sebesar $29,6 \%$. Untuk lebih baik lagi perusahaan harus memberikan penjelesan-penjelesan yang jelas pada karyawan,memberikan pelatihan dan juga melakukan evaluasi pada karyawan. Perusahaan harus memberikan arahan mana yang perlu dirubah dan mana yang perlu diperbaiki untuk menghasilkan kinerja yang tuntas dan memuaskan.

\section{DAFTAR PUSTAKA}

Abdullah, M. Ma'ruf. 2014. Manajemen dan Evaluasi Kinerja Karyawan. Jakarta: Aswara Pressindo.

Arikunto, Suharsimi. 2015. Prosedur Penelitian Suatu Pendekatan Praktek Jakarta : PT. Rineka Cipta

Fahmi, Irham.2016. Manajemen Sumber Daya Manusia Teori dan Aplikasi", Bandung:Alfabeta.

Ghozali, Imam. 201). Aplikasi Analisis Multivariate dengan Program SPSS. Semarang: Edisi Kelima, Badan Penerbit Undip.

Handoko, T Hani . 2012. Manajemen Personalia dan Sumberdaya Manusia. Yogyakarta: Edisi Kelima, BPFE UGM.

Hariandja, Marihot, T.E.(2013).Manajemen sumber daya manusia pengadaan, pengembangan, pengkompesasian, dan peningkatan produktivitas pegawai. Jakarta :PT.Gramedia Widiasarana Indonesia.

Hasibuan, S.P Malayu. 2016. Sumber Daya Manusia. Jakarta: Haji Masagung. 
Hermawati, R dan Nurmalasasi, (2020). Pengaruh stres kerja dan disiplin kerja terhadap kinerja karyawan pada PT. nawakara arta kencana fatmawati Jakarta selatan. Jurnal Ilmiah Prodi Manajemen. Universitas Pamulang, ISSN : 2339 - 0689, E-ISSN:2406$8616,8(1), 77-90$.

I Komang . 2012. Manajemen Sumber Daya Manusia. Yogyakarta: Graha Ilmu.

Kosasih, K., et al. (2020). The Effect of Compensation and Service Period on Employee Performance at PT. Infomedia Nusantara Branch Bandung. Kontigensi: Jurnal Ilmiah Manajemen, 8(2), 147-154.

Kustini, E., et al. (2021). Pengaruh Keterampilan Kerja Dan Lingkungan Kerja Terhadap Kinerja Karyawan Pada PT. Garuda Daya Pratama Sejahtera (Garuda Indonesia Group). Jurnal Ilmiah PERKUSI, 1(3), 305-314.

Mangkunegara , Anwar Prabu . 2016. Sumber Kerangka Berpikir Kinerja. Jakarta Selatan : Gramedia.

Mathis, Robert. L \& Jackson John.H. 2014. Manajemen Sumber Daya Manusia. Jakarta: Jilid 1, Salemba Empat.

Nugroho, Agung. 2012. Strategi Jitu Dalam Memilih Metode Statistik Penelitian. Yogyakarta.

Prawirosentono, Suyadi.2012. Kebijakan Kinerja Karyawan. Yogyakarta:BPFE. Ratundo and Sackett, P. R. 2012. The Structure of Counterproductive Work Behaviors.

Rivai. Veithzal Zainal, S. (2016). Manajemen Sumber Daya Manusia Untuk Perusahaan . Edisike-7. Depok: PT RAJAGRAFINDO

Robbins, Stephen dan Mary Coulter. 2012. Manajemen. Jakarta: PT. Indeks Kelompok Gramedia.

Santoso, Singgih. 2015. SPSS Statistik Parametik. PT. Elek Media. Cetakan Kedua.

Schuler, S Randall. 2016. Pengelolaan Sumber Daya Manusia, Edisi Kesepuluh (Terjemahan), Jakarta: Salemba Empat, Jakarta.
Sedarmayanti. 2016. Manajemen Sumber Daya Manusia, Reformasi Birokrasi dan Manajemen Pegawai Negeri Sipil. Bandung: Cetakan Kelima, PT Refika Aditama.

Sinambela, Lijan Poltak. 2012. Kinerja Pegawai, Graha Ilmu, Yogyakarta. Sinungan., Muchdarsyah. 2014. Pengukuran Kinerja Produktivitas. Jakarta :Bumi Aksara.

Siregar, Syofian. 2011. Statistika Deskriptif Untuk Penelitian. Jakarta: PT Raja Grafindo Persada.

Siswanto dan Agus. 2013. Manajemen Sumber Daya Manusia. Jakarta: PT. Gramedia Pustaka

Sondang, P.Siagian. 2015. Manajemen Sumber Daya Manusia, Bumi Aksara, Jakarta

Sugiyono 2017. Metode Penelitian Administrasi : dilengkapi dengan Metode R \& D, Bandung: Alfabeta.

Suherman, Wawan. 2014. Kurikulum Berbasis Kompetensi Pendidikan Jasmani Teori dan Praktik Pengembangan. Yogyakarta: FIK UNY.

Sunarsi, D. 2020). pengaruh gaya kepemimpinan dan disiplin terhadap kinerja karyawan pada CV. Usaha Mandiri Jakarta.Jurnal Jenius, P-ISSN : 2581-2769, E- ISSN: 2598-9502 1(2 ), 21- 30 .

Supangat, Andi . 2015. Statistika dalam Kajian Deskriftif, Inferensi dan Non Parametric. Jakarta: Edisi Pertama, Kencana Prenada Media Group.

Sutrisno , Edy, M,Si .2016. Manajemen Sumber Daya Manusia, Prenada Media Group.

Suwanto. 2019. pengaruh gaya kepemimpinan dan lingkungan kerja terhadap kinerja karyawan unit telesales pada PT. BFI Finance Indonesia.Jurnal Ekonomi Efektif , ISSN : 2622-8882, E-ISSN :2622- 9935, $1(2), 24-26$. 